Etnográfica

Revista do Centro em Rede de Investigação em

Antropologia

vol. 24 (1) | 2020

Vol. $24(1)$

\title{
The "ethical" soldier? How the Military Police in Rio de Janeiro practice human rights morality
}

O soldado "ético"? Como a Polícia Militar do Rio de Janeiro pratica a moralidade dos direitos humanos

\section{Sara León Spesny}

\section{(2) OpenEdition}

Journals

Electronic version

URL: https://journals.openedition.org/etnografica/8299

DOI: 10.4000/etnografica.8299

ISSN: 2182-2891

\section{Publisher}

Centro em Rede de Investigação em Antropologia

\section{Printed version}

Date of publication: 1 February 2020

Number of pages: 133-154

ISSN: 0873-6561

\section{Electronic reference}

Sara León Spesny, "The "ethical" soldier? How the Military Police in Rio de Janeiro practice human rights morality", Etnográfica [Online], vol. 24 (1) | 2020, Online since 25 February 2020, connection on 20 January 2022. URL: http://journals.openedition.org/etnografica/8299 ; DOI: https://doi.org/ 10.4000/etnografica.8299

\section{(c) (i) (8)}

Etnográfica is licensed under a Creative Commons Attribution-NonCommercial 4.0 International License. 


\section{The "ethical" soldier? How the Military Police in Rio de Janeiro practice human rights morality}

\section{Sara León Spesny}

The Pacifying Police Unit was created to implement proximity policing strategies in some favelas of the city of Rio de Janeiro, Brazil. It was set to reconfigure the relationship between the Military Police and the residents of these neighborhoods, historically based on violence and fear. Drawing from a yearlong ethnography of the daily work of a Pacifying Police station, I argue that this new perspective of policing has set human rights as a discourse that soldiers acknowledge, but find ambivalent and contradictive ways of enacting as a way of morality and police practice. Ultimately, the widely spread public acceptance in Brazil to humanize violence and criminalize rights further influences violent police practices and disrespect for human rights specifically in favelas. Some of the reconfigurations of meanings and practices are related to the selective entitlements of human rights, depending on social categories that not only define and delimit citizenship but also humanness.

KEYWORDS: human rights, policing, Rio de Janeiro, morality, violence.

O soldado "ético"? Como a Polícia Militar do Rio de Janeiro pratica a moralidade dos direitos humanos - A Unidade de Polícia Pacificadora foi criada para implementar estratégias de policiamento de proximidade em algumas favelas da cidade do Rio de Janeiro, no Brasil. Foi criada para reconfigurar a relação entre a Polícia Militar e os moradores desses bairros, uma relação historicamente baseada na violência e no medo. Partindo de uma etnografia de um ano de trabalho diário em uma delegacia de polícia pacificadora, argumento que essa nova perspectiva do policiamento estabeleceu os direitos humanos como um discurso que os soldados reconhecem, mas encontram maneiras ambivalentes e contraditórias de encenar como um meio de moralidade e prática policial. Por fim, a aceitação pública, e amplamente difundida no Brasil, da humanização da violência e da criminalização dos direitos acentua mais ainda as práticas violentas da polícia e o desrespeito aos direitos humanos, especificamente nas favelas. Algumas das reconfigurações de significados e práticas estão relacionadas à aplicação seletiva dos direitos humanos, dependendo de categorias sociais que não apenas definem e delimitam a cidadania, mas também a humanidade.

PALAVRAS-CHAVE: direitos humanos, policiamento, Rio de Janeiro, moralidade, violência.

SPESNY, Sara León (sleonspesny@csu.edu.au) - Institut de Recherche Interdisciplinaire sur les Enjeux Sociaux, École de Hautes Études en Sciences Sociales, France; School of Community Health, Charles Sturt University, Australia. 
"The question of human rights is emblematic of numerous paradoxes generated by the intertwining of crime and rights, violence and democracy" (Caldeira 2006: 106).

\section{A CRIME}

July 14, 2013. ${ }^{1}$ It is probably a sunny afternoon in Rio de Janeiro. A man, Amarildo Dias de Souza, is about to enter his house when he is stopped by police soldiers and taken to the nearest police station for interrogation. He is never seen again. The seventh of twelve siblings, he began working at age 12, selling fruit on the street. He was 43 when he disappeared. By then, he was a husband and father of six. He was one of the many black residents of Rocinha - one of the biggest favelas in Rio de Janeiro and also in Latin America - and worked in construction. According to reports, he was conducted to the Pacifying Police station (established in Rocinha in 2012) under suspicions of complicity with drug traffickers. ${ }^{2}$ He was interrogated and tortured but his body was never found, and neither cameras of the police station nor the GPS of the police vehicles were working. He was known for having a physical condition (epilepsy) that probably resulted fatal when submitted to a forced and violent interrogation. Police agents that worked at the station but were not in the "close circle" of the captain were locked in a section of the station while the torture unraveled. They later testified of what they heard, and suspected. ${ }^{3}$ There is evidence that the major of the station bribed a woman, with a combination of money and threatening her son, to give false witness. Although his body was never recovered, Amarildo's disappearance caused outrage among

I Fieldwork for this project received funding from the European Commission and LabexTEPSIS "Transformation de l'Etat, politisation des sociétés et institution du social". I am grateful to both institutions for their financial support. I also want to thank Susana Durão and Brackette Williams for their insightful comments and suggestions, as well as the anonymous reviewers, as they helped to sharpen its main ideas.

2 See "Amarildo: the disappearance that has rocked Rio," by Julia Carneiro, BBC News, September 18, 2013, available at < http://www.bbc.com/news/world-latin-america-24143780 > (last access in February 2020); “'Cadê o Amarildo?' Pergunta feita em 2013 tomou ruas no Rio e até no exterior," by Ana Cristina Tavares, $O$ Globo, September 30, 2016, available at < http://acervo.oglobo.globo.com/ em-destaque/cade-amarildo-pergunta-feita-em-2013-tomou-ruas-no-rio-ate-no-exterior-20206016\#ix zz4rQjyPfnf > (last access in February 2020); "Where's Amarildo? How the disappearance of a construction worker taken from his home by police has sparked protests in Brazil," The Independent, August 4, 2013, available at <http://www.independent.co.uk/news/world/americas/wheres-amarildo-ho w-the-disappearance-of-a-construction-worker-taken-from-his-home-by-police-has-sparked-protests-in -brazil-8745464.html > (last access in February 2020).

3 See "Caso Amarildo: entenda o que cada PM condenado fez, segundo a Justiça," by Henrique Coelho, Globo.com, February 2, 2016, available at < http://gl .globo.com/rio-de-janeiro/noticia/2016/02/c aso-amarildo-entenda-o-que-cada-pm-condenado-fez-segundo-justica.html > (last access in February 2020). 
people in the community and members of the civil and political sectors of Brazilian society.

But what was so shocking about this death in a context that usually accepts and justifies police violence as the price to pay for public security? Why did Amarildo's situation - contrary to dozens of anonymous victims of police violence in Brazil - cause substantial social indignation, why did it create a moral panic that stirred the public discussion of police, violence, human rights and justice in the city?

Indeed, his death, and specifically the political circumstances of his death, made Amarildo a symbol. In fact, Amarildo's disappearance represents a typical yet also unacceptable transgression of human rights in the country: homicides in the hands of the police, but more broadly, extralegal forms of violence imparted by police. However, one key difference in Amarildo's "case" was that the crime was perpetrated by agents of the Pacifying Police Unit (UPP).

The UPP started off in Rio de Janeiro in 2008 as a groundbreaking project. Directly associated with the internationalization of the city for the World Cup, and the Olympics, the UPP was set up to implement practices that would recover the favelas which were dominated by drug-traffick gangs. It was presented as the renaissance of the Military Police - a police force largely known by its lethality and corruption - within the State. It introduced proximity policing strategies, and, initially, included social programs. It was portrayed as the "entry" of the State into the favelas, and it served as a political and economic tool of the local government to promote a renewed integrated version of a city with striking socioeconomic differences that translates in geographic and symbolic borders. The UPP drew from newly recruited soldiers; mainly young and believed to be "uncontaminated" by the old practices of the regular battalions. Its training curriculum, labelled as progressive by official authorities, included perspectives of human rights and proximity policing strategies and was meant to aid implementing a strategic and sensitive policing guideline to be adapted to the particulars of each favela.

With Amarildo's disappearance, this fragile and rehabilitated hope that the Military Police was renewed by the UPP practices, and the social order these would produce, began to decline. The case revealed the extrajudicial Military Police practices, with all their illegalities and immoralities, were continuing. It also revealed that the "old problems" of the Military Police were not latent but continued to be at the center of police practices. Consequently, the traditional logic of policing was alive and functioning, by which violence continued to be broadly used as the way to impose "order" in these communities.

Thus, when one considers Amarildo's disappearance, it sadly strikes as only partly surprising because his tragic fate was not the first case of abuse linked to UPP soldiers, and it did not prove to be the last (Cardoso 2012). Also, the crime was perpetrated in a favela, communities whose inhabitants the police 
had long discriminated, abused, and inflicted violence on (Zaluar and Alvito 1998; Perlman 2010). Their residents have historically fought for basic rights, services, improved living conditions, as they struggled against political disinterest and everyday discriminations, along with policies and actions that directly threatened and deteriorated their lives. In short, underlying issues of class and race run deep in the history and social marginalization of these communities, and are embedded in a large spectrum of public policies, from housing to sanitation, public health, and specifically, public security (Larkins 201 1; Arias 2006). This history of practice and policy has consolidated a legacy of repression that has systematically suspended human rights. Imbued in what Wacquant calls the "fateful triangle" - economic deregulation, ethno-racial division, and state restructuring - in the age of economic triumphant neoliberalism, the consequences of policies and strategies otherwise said to increase security have been devastating for marginalized populations (Wacquant 2008).

According to data from the Fórum Brasileiro de Segurança Pública (Bueno and Lima 2019: 20), there were 47,215 homicides in 2011 in Brazil, and the rate has grown steadily thereafter; in 2017 , there were 64,078 homicides, with a slight decline in 2018 (57,358 homicides). These numbers place Brazil as one of the countries with the highest homicide rates in the world (Amnesty International 2015: 11). ${ }^{4}$

According to official data, violent death rates in the state of Rio de Janeiro have had an overall drop in the last two decades, from a staggering $60.3 \mathrm{homi-}$ cides per 100,000 inhabitants in 1991, to 39.4 homicides per 100,000 inhabitants in 2018. ${ }^{5}$ But, even with this plunge, homicide rates are considered critically high. Between 2010 and 2013 - when the pacification strategy was at its peak - there were 1275 victims of police killings (homicídio decorrente de intervenção policial): 99.5\% where men, 79\% where black, and 75\% where aged between 15 and 29 (Amnesty International 2015: 5).

In 2014 - when this fieldwork took place - police killings accounted for $15(6 \%)$ of the total homicides in the city of Rio de Janeiro (Amnesty International 2015: 5). In broad terms, favelas represent the margins of this war on drugs, even if the UPP program did significantly reduce police killings. ${ }^{6}$ So,

4 The report of the Fórum Brasileiro de Segurança Pública (Bueno and Lima 2019) combines data from the state secretaries of public security and social defense, along with other sources. Nevertheless, public security statistics in Brazil are difficult to analyze. Lack of a national network, different state criteria and terminologies as well as a questionable registration of accidents are all part of the issue (Andrade and Szwarcwald 2007).

5 See "Séries históricas anuais de taxa de letalidade violenta no estado do Rio de Janeiro e grandes regiões," Instituto de Segurança Pública, 2019, p. 3, available at < http://www.ispdados.ri.gov.br/Arquiv os/SeriesHistoricasLetalidadeViolenta.pdf $>$ (last access in February 2020).

6 In 2007, before the implementation of the UPPs, police killings represented 14.6 per 100,000 inhabitants and the number decreased to 3.5 in 2013; however, these rates are quite unstable and there has been a progressive increase since, to 7.1 in 2016 (see "Séries históricas anuais de taxa [continues] 
Amarildo's torture and disappearance pointed to the difficulties of implementing top-down ideas in a militarized institution such as the Brazilian police, specifically with regard to policing practices that acknowledge and respect human rights.

The police struggle with ambiguous goals that include fighting against "internal enemies" - a heritage of the dictatorship - and respecting human rights - a modern imperative for State institutions. From social services to surveillance, whatever the site and topic of struggle, invoking human rights has become part of voicing social demands. The resulting human rights discourse has been integrated with great difficulty into official agendas of the post-dictatorial countries of South America. However, as Teresa Caldeira (2006: 106) points out, the case of the human rights is paradigmatic in Brazil because it reveals the constant tension between crime, violence and democracy. Given the fact that the country displays some of the highest rates in homicides and police killings, the human rights narrative - and police morality it supposedly disseminates - reveals other sorts of tensions between notions of freedom, repression, humanity, punishment, and dignity.

\section{VIOLENCE, HUMAN RIGHTS AND POLICE WORK:}

\section{PARADIGMATIC ENTANGLEMENTS}

According to Mark Goodale, human rights have become radically engrained in the "dominant contemporary logic of personhood and social and political change" (2012: 468). Indeed, as Goodale goes on to argue, the discourse of human rights has become essential in the Western constitution of the neoliberal self. As an overall encompassing notion of personhood, this view of self has come to define the relationship between people and institutions, between the State and its populations. For this view, human rights discourse and police work have been particularly problematic, because police work has a complex relationship with violence. The frictions between human rights and police work come from theory as well as practice. On a theoretical level, since Weber (2004) identified the State's monopoly of the legitimate use of internal and external violence, police have been legitimated as the major authorities for the State's internal violence. Police practice involves a wide range of legal and extralegal forms of violence. Acceptance of police discretion for a valid use of violence is often seen to be a cause of abuses or excesses that violate rights. Thus, at the very least, police work and human rights are often regarded as antagonistic. 
As a way to tackle this strained relationship, police forces have led efforts to replace "the suspicion of an excess of violence" which directly contradicts the discourse of human rights with a distinction between rational and irrational violence. Rational violence is accepted as legitimate and not directly antagonizing a human rights discourse. This transformation of rational - as legitimate - violence takes shape through its quantification, and "objective" criteria to measure proportionality and minimum needed force (Hornberger 2010). However, the triad of violence, police work, and human rights is constituted by a paradoxical tension that does not seem to be reconciled easily.

In general terms, Julia Hornberger (2010) points out, inspired by a Foucauldian perspective, that human rights might be interpreted as soft technologies that try to establish a moral truth that would lead to voluntary adherence. Hence, human rights operate more as persuasion to a moral adherence than as laws and judiciable bindings. Within the police, human rights are usually presented in the form of workshops, training courses, codes of conduct, conferences and inspections that seek to persuade police officers to act according to a moral behavior set by the framework of human rights. Can we accept human rights as soft technologies that aim to moralize police work? According to Goodale, human rights can indeed be conceived as a moral practice in the sense that "the notion that morality itself should be understood as a kind of social practice [...] in terms of which, the subject is shaped, framed, and reframed" (Goodale 2012: 470). Therefore, Hornberger remarks that "human rights thus can best be described as technologies of the self and knowledge practices about law rather than a legal practice per se" (2010: 268).

In particular terms, focusing on violence against women, Sally Engle Merry (2006) analyzes how human rights become interpreted and meaningful in local social settings. She reveals how "imposed" notions, such as human rights, travel to small communities, and are typically vernacularized, i.e. adapted to local institutions and meanings. A series of reconfigurations of meanings and practices take place in this translation in the move from the place of origin, in this case, the global North, to the place of reception, the global South, and the specific institutions and settings within the city and neighborhood.

Daniel Goldstein, building on Merry's notion of vernacularization, argues that we must avoid thinking that language and concepts follow a linear trajectory from the global to the local, as a sort of gift that the Northern world has gracefully given to the undeveloped South:

"Vernacularization, instead, describes a process of reception and transformation, a dialectic in which transnational conceptions are made meaningful within, or rejected on the basis of, local realities, themselves already conditioned by their broader inclusion within transnational frameworks of economics, politics, and culture" (Goldstein 2012: 211-212). 
This framework allows us to look at human rights as a dynamic construction by various actors, in which concepts are interpreted and inserted in a specific setting and its cultural and historical particularities. While a Foucauldian-inspired notion of human rights as a technology of the self, questioning how an ethical subject is made and remade, vernacularization focuses on the social adaptation of the human-rights notion, in historical and collective contexts. They both attend to the possibility for transforming and reshaping discourses and practices, bringing together the individual and social dimensions.

For Hornberger, what is most important about "policing vernaculars" is that the "engagement with human rights discourse transforms the subjects and their possibilities for a particular kind of meaningful practice at the same time that the subjects reshape the discourse and the field of practice" (2010:270). In a broad sense, "much of the anthropology of human rights has examined this growing gap between what might be called 'expectations of universality' and the lived reality of violence, ethnic discrimination, and political exclusion" (Goodale 2012: 469) In a particular sense, policing studies - especially ethnographies - have become a privileged platform to highlight the delicate relationship between human rights discourse, police action, everyday practices, and ordinary notions (Fassin 2011; Jauregui 2016; Willis 2015).

The contradicting views of human rights and the police in Rio de Janeiro have been considered especially radical (Miranda 2014; Leandro and Figueira 2014; Cano 2006) by ethnographic perspectives pointing towards the many transgressions and violations and highlighting the tensions and paradoxes revealed through daily work. It is thus a fertile ground to study the strains, intersections and junctions that emerge when contemporary police forces interact with their public.

Other ethnographic accounts of the UPPs have investigated the social unfolding of the policing strategy and the pervasive effects on the lives of residents (Menezes 2014, 2018), as well as the continuum between peace and war in pacified favelas (Leite 2012, 2014). The ethnographic accounts of Menezes (2014) and Leite (2014) - besides work by other scholars such as prominent sociologist Luiz Antonio Machado da Silva (Silva 201 1; Silva and Leite 2014) -, in particular, have accounted for the everyday life of the favelas, notably in its ambivalent relation between social abandonment and military intrusion.

During my yearlong ethnography in a UPP Military Police station, I carried out observations of the daily activities of soldiers seeking to shed some light on how the Military Police work vis-à-vis the social order and how, from the point of view of these soldiers, this order constantly challenges the moral, civilizing enterprise of the pacification process. I followed foot patrols, vehicle patrols, and the routine work of a UPP station, always during the day shift. Most of my information came from observations but also informal conversation with 
agents. I carried out some formal interviews directed towards higher hierarchies of the police and other stakeholders (NGOs, for instance). Since my interest was to look at the interaction between the police and its public - the residents of the favela - I spend most of my time with soldiers and sergeants. Soldiers are police officers that patrol the streets and sergeants are operational supervisors of each shift; in the military hierarchy both are lower ranks (praças), acting under the higher ranks (oficiais).

Indeed, human rights discourse shape and "transform the subjects and their possibilities" (as Hornberger has pointed out) and reveal and discuss some of the frictions, tensions and daily interactions that place human rights discourse at the forefront of policing. I will not discuss a particular set of human rights, such as the right to live, as the introduction would suggest. Instead I will refer to human rights in a more or less loose or diffuse and ambiguous form, similarly to what police soldiers did in their day-to-day life, to what emerged in conversations or what I saw during patrols. It is also through the more "banal" or forgettable cases of violation of rights that we can comprehend how the discourse of human rights actually affects police work. I will focus exclusively on teams that were in charge of patrolling the favela, both from the proximity policing group - GPP (Grupamento de Polícia de Proximidade) - and the tactical policing group - GTPP (Grupamento Tático de Polícia de Proximidade) - in a specific UPP station that will remain anonymous. Roughly, while both teams patrol the community on foot, the GPP works with a "softer" approach (marking police presence) and the GTPP is active in repressing weapons and drugs. I am excluding from this analysis other UPP activities, as social initiatives organized by agents of the station that are considered "an extension of police work" and include language, music and sports lessons, workshops, parties and charity events. This would certainly bring to the forefront a wider range of discourses regarding human rights, but I chose to focus on the street patrols because they certainly have a direct and constant contact with the residents of the community. I argue that these subtle forms of resistance and contestation, adherence and recognition shed light on the way human rights discourse constitutes a moral framework that influences, but by no means determines, police work, to present a somewhat broad picture of how human rights discourse affects and shapes policing practices and subjectivities.

I aim to discuss, from an ethnographic perspective, the relation between violence, police work and human rights within a paradoxical tension. This tension is fostered in everyday policing, through interactions with the "obvious" interlocutors of the police, this is "criminals" and "suspects," but also with other social categories, such as children. In this sense, I conceive human rights through their practical and symbolic resignifications, meaning as they are shaped and mobilized in specific situations. In fact, it is within these specific situations that the paradoxical tension is revealed. I proceed through the 
account of three scenes from my fieldwork in which the police encounter a "criminal" (bandido), a "suspect" (suspeito) and a child (criança).

HUMAN RIGHTS: FROM A UNIVERSAL TO A RESIDUAL

AND CONTRADICTORY NOTION

\section{Fantasy (the "bandido")}

"Two soldiers, Silva and Faria, are on patrol. One holds a rifle (fuzil), while the other holds a handgun. Silva and Faria are working with coordinated precision, as one walks forward the other one checks behind him pointing with the fuzil, and so they go. Always one protecting the other. Silva walks pointing his handgun ahead. They are [...] quiet, so I try to respect the climate. Today, they are extremely cautious, and I ask Silva if 'the climate is tense'; to my surprise he denies it sharply, returning to the silence of the patrol. At one point, we arrive at a pracinha, a small square, just in front of someone's house. There is a refrigerator and a washing machine. It is unclear whether these are garbage, as they seem in fairly good state, but they are seemingly outside, as if part of a pile of garbage that is spilled around. As the soldiers arrive, they immediately search inside the appliances. A floral design blanket covers the washing machine, and Silva pulls it off roughly and, after perceiving that there isn't anything in there, he repositions it with little care, even an aggressive gesture. Before they resume the regular pace of the patrol, Silva, going down a straight set of stairs, sees an olheiro [the person set to announce to other members of the local traffic gang that the police is near]. Silva takes out his gun immediately and hides, by trained reflex, behind the washing machine. At that same moment, Faria tells him to hide, and he answers that he has already been seen (Ele já me viu, já me viu) holding his handgun with both hands. Silva rises from behind the washing machine, and standing with a strong pose, holds his handgun with one hand. Silva points his gun in what appears to be direct aim at the olheiro. He closes one eye. I am motionless, in a corner, and I am not able to see downwards. He stares at him and then pulls the trigger, 'click'. He did so without loading the gun, at least not this time. I don't know if the olheiro saw the soldier pointing at him and pretending to shoot. Soon after, Silva records a message in an instant messaging platform that keeps the sargeant and other members of the team updated. Still shaken by adrenaline, Faria points with his fuzil up and down. Silva gives the description of the young man (suspeito de boné vermelho, bermuda branca descendo) and says he recognizes him; in fact - according to Silva - he is well known to the police as an olheiro of the local gang. Faria tells Silva, 'let's go scare them, let's go get them' (vamos espantando eles, vamos descer, vamos descer). They are deciding 
whether to pursue the interaction. And while sometimes one of the soldiers launches himself at the suspect, this time they decide not to hurry after him. We resume the pace, walking carefully downwards. At the end of the patrol, Silva wasn't upset to have 'lost' the olheiro (as I had observed before during brief interactions between the police and their public, specifically with young men). On the contrary, he seemed satisfied; telling Faria, 'if I would have wanted, I would have killed him' referring to the olheiro" [from the author's fieldnotes].

Silva's fantasy about shooting a suspect is twofold. On the one hand, he explicitly evokes the shooting, an exaggerated punishment for running from the police. His lack of action revealed a fantasy of being able to act on one's desired intention by simulating the action not taken. On the other hand, he admittedly demonstrates the disposition as desire to shoot a criminal without legal justification. This is of course the case only if we do not assume, as he did, that the young man was part of the local traffic network, and therefore, a bandido. Silva demonstrates ambivalence about acknowledging human rights when facing serious difficulties dealing with criminals that he assumes do not deserve these rights. In assumption, Silva is not an exception. Instead, his logic is rooted in the rise of human rights in Brazil, the implementation of which came some time after the country's democratization and was directly linked to the fight against the arbitrary use of force by the military dictatorship. Human rights became one of the symbols of a new national project. The language of human rights arose in Brazil during the 1980s, in part through international rights organizations (such as Amnesty International, Americas Watch), and in part through a sector of the Catholic clergy (Scheper-Hughes 2006: 153). Social movements were key actors that forced an end to the military dictatorship and became essential to the integration of rights and citizenship in the 1988 Constitution (Caldeira 2006: 105). This Constitution was one of the most progressive of its kind, and it gave special attention to minorities, including women, children, prisoners, peasants, urban workers, squatters, and shantytown dwellers, giving recognition of the country's racial inequalities (Scheper-Hughes 2006: 151; K. Silva 2014).

Based on the popular notion that justice and rights in Brazil are privileges, some sectors of society identify human rights as "privileges for bandits," in contrast to a prevailing view of the justice system as one reflecting deep inequalities, inefficient and unjust, and within which only those who have high socio-economic capital have the power and resources to influence it to their own advantage. Thus, "those campaigning against the notion of human rights, asked if justice is a privilege and if the majority of citizens have their rights disrespected systematically, why assure rights (privileges) to criminals" (Caldeira 2006: 107). 
The association of rights with privilege was so powerful that it took about a decade to begin to disassociate these ideas about rights from the conclusion that they meant "privileges for bandits." These are new efforts, mostly since the mid-90s, and these ideas have by no means completely faded in the social imagination. The politics of human rights during this process created conditions that reaffirmed differences and the recognition of inequalities (K. Silva 2014). Consequently, if we interpret this genealogy, the relation of the discourse of human rights, from its inception, has been vulgarly associated with bandidos. Further, if we take for a fact, as Silva did, that the young man running was a known member of the local gang (a bandido), then what the soldier demonstrated was that the man's life was not entirely worthy, and he could be shot.

In sum, a notion with universal pretentions has been shaped into a residual and contradictory challenge to practices, that in many ways has yet to become a fully acceptable democratic idea. Vernacularization of human rights in Brazil, even at the national level, demonstrates strong local traits, based in the historical and social conditions that still have clear racist and classist roots. The favela is the location where many of these contradictions and vernacularized notions can be discerned as they are actually performed. Maybe Silva's actions demonstrate just how ambivalent these notions became, especially in police work. Building on what we learned from Silva's pretended shooting, in the next section we explore scenes that reveal human rights as technologies of the self and how these can influence police behavior.

\section{THE RISE OF ETHICAL SOLDIERS?}

\section{Temptation (the "suspeito")}

“'It's better to hit a wall than hit a suspect,' Riveiro would murmur as he accepted, with half shame, half anger, that his suspect had escaped through the narrow alleys. After a rather fast, but long, chase downwards, soldier Diego and I catch up with Riveiro. His breath is heavy and drops of sweat running down his face almost seem like tears. His cheeks are flushed and the veins in his face are plumped. His big black, almond eyes convey a mixture of anger and disappointment. As we approach him, he is holstering his handgun; the final sign he has definitely given up the chase. Moments later, Riveiro unleashed his anger against a wall. His knuckles, cracking against the cement, sound like a chain of small explosions. He launches his right hand with what seems to be the full weight of his body. He repeats the punches a couple of times. For a few seconds, Diego and I watch him, perplexed, unable to do anything except witness the fragility of skin and bones as they meet with the immutable cement wall. Diego seeks to calm him down by 
telling him that the suspect is 'just a boy that probably ran just because he was scared of us,' as neither of them recognized him as belonging to the traffic (ele nem pertencia ao tráfico), but Riveiro strikes back reminding him that o tráfico is constantly recruiting, and they shouldn't be naïve about it. I talk to him afterwards, asking if he was OK, and he responded, looking at his knuckles with a grimace, 'It is nothing, I don't even consider it a scratch.' And, as he realizes I am looking for an explanation, he continues, 'You see, if these were the old times, I wouldn't have to hit a wall, I would have just been able to hit the suspect' (Olha, se fossem outros tempos... ah se fossem outros tempos, eu poderia bater no suspeito, mas não, agora eu bato na parede), seemingly ignoring the fact that his 'suspect' had effectively escaped. 'But with all this human rights talk, we have to control, measure, what we do or don't do with everyone, even if they are suspects, you see?' (Agora com toda a questão dos direitos humanos, essa fala, temos que nos controlar, mensurar o que fazemos, ou não fazemos, né, com todo mundo, mesmo se são suspeitos, né?). We continue to chat for a bit about this 'human rights talk': 'You see, people in general think that things in the world are free, everyone wants to be free to do whatever, but the truth is, nothing is free in this world, we all pay a price. Human rights also have a price, you see?' (Olha, o pessoal acha que todo mundo é livre, todo mundo quer ter a liberdade de fazer o que eles quiserem, liberdades, liberdades, mas, na verdade, neste mundo, nada é de graça, todos pagamos um preço, sabe? Direitos humanos não é de graça tampouco). It seems that the mounting frustration of 'loosing' suspects had finally taken its toll on Riveiro that morning. Riveiro's knuckles seem to bother him for the rest of the day. While not much blood was shed, his skin was left bruised and scratched. He looks to his right hand numerous times during the rest of the patrol. Maybe he did so out of sheer pain, but probably the looks also reminded himself of the suspect who had escaped. In a way it seemed that Riveiro thought of the bruised hand as if injuries had been inflicted directly by the 'suspect', and not as a self-infliction damage done in rage. Would Riveiro be as 'forgiving' next time with a suspect? Would he have done otherwise were I not watching? There are certainly many possibilities I have to ponder on, and deal with the uncertainty of their answers. However, what Riveiro demonstrated was that his anger had to be physically expressed. He could not contain his emotions even if he acknowledged that he should adhere to certain police practices, such as not hitting 'suspects'" [from the author's fieldnotes].

Riveiro was a young Military Police soldier. He was recruited and trained specifically to work at the UPP project, so it struck me as surprising to hear him compare how one could behave in the "old times" and at present. When I look back at his physical reaction I would not be stunned to know that the soldier used violence as part of his practice, but what also seemed surprising 
was the sense of self-control that he expressed, as a sense of restraint was now imposed upon him, constructed in the shape of "human rights talk." Whether he believed this notion or not, human rights had become a set of ideas that now permeated his daily work, if only when an external eye was watching. For Riveiro, human rights talk demanded a sense of measure and control from police officers, and, even if this took a personal toll on them, officers were obliged to respect these ideas at least to a certain extent. In this sense, the Foucauldian perspective of human rights as technologies of the self comes to focus. The ambivalence Riveiro demonstrated (being violent or not) demonstrated how he - as a subject - struggled to be shaped and constructed and how human rights as a notion managed to crawl under his skin and began to operate.

Nonetheless, Riveiro's personal submission to self-control has also been an institutional objective. Indeed, the Pacifying Police Unit has transferred international knowledge and adopted the goal of achieving respect for human rights. At least partly, it seems that the internal organization of the Military Police has made efforts to impose control over police violence and abuse. The Police Ombudsman Office (Ouvidoria da Polícia do Estado do Rio de Janeiro) was created in 1999, a time when human rights movements gained renewed strength and after serious rights violations from the police in the city (Amnesty International 2015: 5). The ouvidoria represented, at least to some extent, a control on the police practices. In the official website, the mission of the ouvidoria was defined by statements such as: "when you denounce a deviate policeman, you participate in the social control of an excellent police institution." " The specific ombudsman for the UPP was created in 2014 under the slogan "Peace with Voice" (Ouvidoria Paz com Voz) and also after serious rights violations, such as Amarildo's disappearance. Encouraging a direct line of communication with favela residents, this ouvidoria has promoted its presence by making a unit that stops in each community several times a year. In addition, in 2015 the Military Police announced that it was extending and qualifying military training for all aspiring police soldiers, from seven to twelve months, increasing to ten the theoretical seminars (focused especially in proximity policing and human rights) and including two supervised internships (practical learning). ${ }^{8}$ In the official website of the Military Police, an article

7 "Quando você denuncia um policial infrator, você participa no controle social para uma polícia de excelência. Quando você elogia, você valoriza um bom policial. Quando você sugere, colabora com a Segurança Pública do Estado do Rio de Janeiro" (retrieved from < http://www.ouvidoriadapolicia.rj.gov. $\mathrm{br} />$, no longer active).

8 According to the Military Police's website: "O novo curso de formação contará com 32 disciplinas. Nove delas receberam aumento de carga horária. Entre elas estão: Direitos Humanos (de 16 para 20 horas/aula); Imagem Institucional (de 8 para 10 horas/aula); Língua e Comunicação (de 24 para 30 horas/ aula); Instruções Práticas de Ações Táticas I, II e III (de 70 para 114 horas/aula); Noções [continues] 
explained this new perspective, describing that "new policemen should administer possible controversies and minimize their chances of conflict inside the pacified communities, the soldiers should have the knowledge and habilities to administer conflicts, and be prepared to attend the demands of the population." 9

More recently, a specific team (O Grupo de Atuação Especializada em Segurança Pública - GAESP) within the Public Ministry was created to tackle the mounting cases of police abuse and violence. ${ }^{10}$ But have these legal - and moral entrepreneurship efforts been effective controlling abuse and violations perpetrated by the police? According to Human Rights Watch, from 1999 to 2009 the Ombudsman's Office registered over 7,800 civil complaints against the Military Police officers concerning criminal conduct, but these complaints generated only 42 criminal charges by state prosecutors and from those, only four convictions were sentenced (Human Rights Watch 2009: 6). This numbers exemplify that despite efforts to implement internal and external controls within the Military Police and specifically with the UPP, these mechanisms seem to render little results.

Riveiro's reaction ultimately reveals that human rights as technologies of the self and knowledge practices are still an intimate source of ambivalence and resistance, in which "knowledge" is difficulty paired with "practice." The following scene also depicts these tensions and contradictions, but while the bandido or the suspeito are the usual interlocutors of the Military Police and can be described as the naturalized enemies of the police, the figure of the child is also polarizing when it comes to human rights and police work.

\section{HUMANIZATION OF VIOLENCE, CRIMINALIZATION OF RIGHTS}

\section{Malaise (the "criança")}

"I am following Débora and Márcio, two soldiers on patrol. We are making our way through the narrow alleys of a favela. It is a clear afternoon. Débora, a female soldier is guiding the patrol. She is in her early thirties,

[continuation] de Direito Administrativo (de 12 para 16 horas/aula); e Legislação Processual Penal Comum (de 8 para 12 horas/aula)" (in < https:/pmerj.rj.gov.br/2015/10/formacao-de-pms-tera-duracao-ampliada-em-2016/>, last access in February 2020).

9 "Queremos que o policial formado tenha conhecimentos e habilidades para administrar conflitos, tendo a capacidade de realizar processos decisórios. É importante reforçar também que o PM estará sendo preparado para atender às demandas da população, sendo que a força letal será o último recurso adotado" (PMERJ, in < https://pmerj.rj.gov.br/2015/10/formacao-de-pms-tera-duracao-ampliada-em-2016/ > , last access in February 2020).

10 Through the "Resolução GPGJ 2.021," December 30, 2015, available at < https://www.mprj.mp.br/ documents/20184/418907/Resolucao_2021.pdf > (last access in Feberuary 2020). 
mother of one, married. Her light skin with abundant freckles around her cheeks and big green eyes are expressive as she talks. She wears makeup, delicate black eyeliner and a glittery neon bright pink lipstick. Her nails are neatly painted in soft pink, and her bonnet is carefully arranged with a pony tail on the back. She entered the Military Police - despite determined critique from her family and friends - looking for a stable salary and motivated because she 'didn't think it was a bad job' (eu não achava ruim a ideia de ser policial). Márcio, the other soldier on patrol, is younger, is in his midtwenties. He has dark skin and small black eyes that seem framed close together. He is quite short and substantially thinner compared to most young soldiers at the station. Márcio entered the Military Police also with hopes of a stable salary and encouraged by the idea of working as a military man. Débora tells me that she has previously worked in two other UPPs. Márcio reveals that he used to work in UPP Rocinha. Before I was able to reply, he states, 'Yes, I worked there during the Amarildo case, but don't worry I had nothing to do with that, I wasn't even at work that day (estava de folga).' He explained that all the soldiers who worked at that station during the disappearance of Amarildo, including those who weren't involved were transferred for security reasons. He makes it clear that talking about Amarildo makes him uncomfortable. Trying to prolong the subject is like touching a raw nerve. 'It's complicated', he repeats several times and finally putting an end to the conversation that he appears to regret having started in the first place. Débora and Márcio are part of the proximity troop (Grupamento de Polícia de Proximidade - GPP), so they have to make an effort to be friendly with residents. Even if they both express a degree of distrust and skepticism towards favela residents, they are aware of their role: 'We must say hello, talk to them, this is what the GPP does,' even if their self-described kindness is not always reciprocated by residents. On their patrols, they do make an effort, but selectively: women, children and elderly usually are perceived with benevolent eyes while adolescents and young men are labeled a priori as suspicious. Márcio was especially critical of the functioning of the UPP project. He seemed extremely disappointed with the high hierarchies of the station, expressed in what happened to Flávio a few days before. Flávio, a colleague soldier was sanctioned and transferred to another UPP station for stopping, frisking and intimidating a 12-year-old resident who was caught with 1000 reais in cash (about 320 US dollars). 'This was during the World Cup so there was a lot of pressure.' Márcio states justifying the commotion the police action generated. Flávio insisted that the boy explained why he had 'so much money' on him and was determined to conduct the boy to the Delegacia (the Civil Police station) where, according to the law, he would not be arrested but a file could be opened involving his legal representatives. The proportions of the episode grew, and several residents and police soldiers 
recorded the event and then posed complaints before the station's captain. In response, the captain transferred Flávio to another community, to avoid malaise within the community and maintain a level of legitimacy in the eyes of the residents. The captain's reaction to the episode managed to contain the community's indignation but unleashed the malaise within his troop. So, for Márcio, Flávio was just 'doing his job’; besides, he commented, 'it isn't normal for a 12-year-old to have that much money in cash, that is the tráfico,' he concluded, 'it has to be, nobody has that kind of money like that.' Indeed, Flávio's transfer seemed unjust and unsupportive and even absurd. Márcio has the recording of the event on his portable phone. He shows it to me. The video begins when the commotion had already started and does not show an actual aggression towards the child, but it does testify for the disorder it created. People are screaming at the police officers that gather in front of the child, while backup police officers arrive at the scene. The child, a thin black boy wearing baggy shorts and sandals (chinelos) seems scared. He is leaning against a wall with both hands behind his back. Next to him a women complaining to the police, she seems to be a relative or friend of the child by the way she is defending him. The screaming and shouting makes inaudible any form of dialogue. Márcio looks at the video as trying himself to make his mind about the event, and his explanation leads to a cathartic moment. He tells me: 'Recently human rights have gained a lot of space, too much, especially for children. This reduces our autonomy in our work, we are not able to do our job with all this human rights talk. Here, everyone has rights but nobody has duties' (Todo mundo tem direitos mas ninguém tem deveres). I have never hit anyone, you know? But I think if we end up in an episode [referring to Flávio's interaction with the boy], what are we going to do? Shoot everyone? We can't' (Se se faz tumulto em cima, nossa! Que vamos fazer? Dar bala em todo mundo? Não pode)" [from the author's fieldnotes].

Márcio's understanding of human rights is one more example of how the initial universal pretention of human rights seems to fall short in practice. For Márcio, the young boy was one more threat and human rights rose only to protect him, but rights have "gained too much space" and now over-protect. He also immediately associated the "human rights talk" with violence, as he evokes hitting and shooting, and he does so referring to "anyone" and "everyone." The example is further illustrative because he is referring to a child. The image of children usually associated to vulnerability and innocence is framed - on the contrary - as a threat.

This interphase can reveal the parallel acknowledgement and denial of entitlement to human rights for favelas' residents in general, children included. Thus the social acceptance in Brazil when it comes to humanize violence and criminalize rights. With the soldiers, this movement can be enhanced, due to 
several factors, including the strong hermetic character of the institution, the institution's colonial and dictatorial heritage, and the daily experiences and representations of patrol and surveillance in favelas.

The scenes I depicted with Silva, Riveiro and Márcio show how human rights constantly emerge in the daily life of Military Police work, be it during patrols or in casual conversations. But the spectrum of human rights appears in the form of dilemmas, contradictions and tensions, where actions and emotions appear irreconcilable with the universal idea of human rights.

I often heard the expression "human rights for humans." If we take this phrase seriously, we understand the implicit ontological differences of what it means to "be human" in Brazil. It also puts human rights on the forefront of police work, as well as the delicate relation between them. In this sense, soldiers usually give moral justifications for that statement. For instance, human rights correspond to humans, "not to people that transgress the rights of other people" (Direitos humanos para os humanos, não para pessoas que transgridem os direitos de outras pessoas), that is, not for "criminals" (criminais) or "bandits" (bandidos). So, there is a clear distinction between different forms of citizenship and even human beings. But we also see that these distinctions are not clearly defined, as a child can also represent the undermining of police work due to the "human rights talk." As Jaime A. Alves argues, the expression "human rights for humans," "often used to justify police killings in Brazilian favelas, just illustrates the 'racial common-sense' that informs the logic of justice and punishment: the victims don't have rights if they are not considered fully human, and Blacks are not quite humans" (Alves 2014: 145).

In general, soldiers expressed the difficulties of integrating human rights is their daily work: "I'm not against [human rights] but there have to be limits; it does make our work harder" (Não é que eu sou contra os direitos humanos, mas tem seus limites. Dificulta nosso trabalho) is a general phrase that summarizes what many soldiers would express.

This fragmentation regarding who is - and specifically who isn't entitled - to have their rights respected certainly shapes a residual and often contradictive notion of human rights. Here, even if the concept is acknowledged, it is selectively appointed to certain categories of people while it is withdrawn from others. Whereas the "criminal" or the bandido representing the "people who do not respect the rights of others" are not entitled of rights themselves, other figures, such as the child, still pose a challenge to some soldiers that perceive them as a threat.

Márcio's malaise with the integration of human rights and his verbal expression of this apparent incompatibility sets a contrast to Silva's fantasy or Riveiro's temptation. One is rational and verbally communicated; the other two are embodied and emotionally expressed. Their similarities reside in the fact that human rights are seen as a limitation of police power and that they 
must work around them in their daily experience, be it by pretending to shoot, hitting a wall or simply expressing disillusion. As Silva and Riveiro's anger is visible, Marcio's account of how Flávio was transferred points towards a resentment (Fassin 2013) for how the "human rights talk" incapacitates them to do their work.

According to Merry's vernacularization, the notion of human rights is constructed with these mentioned nuances within this local context. Some of the reconfigurations of meanings and practices are related to the selective entitlements to human rights depending on the category that not only defines and delimits citizenship but also humanness. In such a context, there is a constant tension between the humanization of violence and the criminalization of rights.

On the another hand, all the scenes described above help exemplify "the unpredictable moments of self-constitution that characterize the practice of human rights-as-moral practice" (Goodale 2012: 478-479). But these moments of self-constitution (and thus the actor's rise as ethical subjects) happen in fragmented, ambivalent and often partial ways. The three soldiers express acknowledgment but difficulties in transforming human rights in a moral practice.

But like the police, residents of favelas in Rio de Janeiro categorize and distinguish rights within parameters of good and evil, more specifically differentiating "good people" (pessoas do bem) and traffickers (bandidos or o movimento), and valuing the condition of "contributor" or the one who "pays his bills" (pagador de contas) (Cardoso 2012). As Caldeira has also noted regarding residents of poor urban peripheries in São Paulo, "they discovered that being taxpayers legitimated their 'rights to have rights" (Caldeira 2006: 104).

A common claim of residents is that police officers are incapable of distinguishing traffickers from "good people" (pessoas do bem) (Cardoso 2012: 495). As Cardoso explains, the distinction favors those who are inscribed in the labor world, proving to be ethical subjects through the guarantee of work ethics and dignity, which should ensure "the subjects to have their rights respected by the police" (Cardoso 2012: 499). Residents also expressed through their narratives that they thought "the right to receive a respectful treatment to be related to fulfilling their duties, such as paying for water of electricity" (Cardoso 2012: 502). Thus, for residents too, "nothing is free" and "everything has a price," including human rights.

Far beyond external mechanisms of control and internal education for soldiers, collectively shared constructions and representations of figures such as the "resident" (morador) and the bandido are perhaps historically-charged tags that have been socially imposed to the residents of favelas and this enforces a certain duty of the Military Police to control and dominate this populations, at whatever cost. In fact, as Teresa Caldeira has argued, paradoxically police 
forces who kill - or act with violence - are often perceived as enforcing the rights of citizens (Caldeira 2006: 109-110) in the name of security and justice. This shows what Perugini and Gordon have claimed, that sometimes the prevailing logic is that "violence protects human rights from the violence that violates human rights" (Perugini and Gordon 2015: 3).

As we saw, the historical constitution of human rights in Brazil - at the confluence of democratization and authoritarian rule - has largely shaped values and emotions associated to the very notion of human rights. The Military Police are precisely those how enact this constant tension between the humanization of violence and the criminalization of rights through their daily interaction with the residents of the country's low-income neighborhoods.

Human rights should be thought of as a layered concept, one which exists as a universal notion that must be implemented in specific settings, as a moral-civilizing discourse, as a set of moral rules that guide actions. But it's underbelly is equally layered, one which exists as a banalizing discourse, as a justification of violent policing, and ultimately as a political discourse that sustains diverse forms of military intrusion in the favela. Indeed, we need to ask ourselves whether the discourse of human rights is actually integrated within police work (and thus, involved in the constitution of a new morality of policing) or it is invoked as a renewed form of military intrusion.

\section{A CONCLUSION: POLICING HUMAN RIGHTS?}

"Human rights for humans" can translate the contradictions on the "rise" of the discourse of human rights in contexts of violence. It can also lead towards an analysis of how ethical subjects - and specifically police officers - are shaped within contexts of local violence and conflict.

To analyze how "human rights both foreclose and enable possibilities to act and to be" within police forces reveals the "ineluctable tension" police officers are confronted to and which they must "negotiate in various ways" (Hornberger 2010: 270). In this sense, the Foucauldian perspective of human rights as technologies of the self allows us to grasp the ambivalence that Riveiro, Silva and Márcio demonstrated or expressed. All three soldiers demonstrated how human rights operate as a notion and how they - as subjects - struggle to be shaped and constructed according to these diffuse technologies that ultimately set up moral parameters. So, human rights can be interpreted as police practice but also a new form of morality that managed to transform the subjects and their possibilities, but always at the cost of ambivalence and contradiction. At the same time, the perspective of vernacularization allows us to understand that human rights are not monolithic concepts that are accepted or rejected in their whole. On the contrary, they are notions that express tensions, contradictions and dilemmas in the daily life of subjects, in this case, 
soldiers of a Pacifying Police station. In this sense, maybe what is harder for the soldiers is precisely the fact that human rights are imposed before them as a moral mandate, one that should shape their presence in the world, however this moral mandate seems to contradict common sense notions and ideas associated to human rights, such as the "rights-as-privilege" stance that is so engrained in Brazilian thought. These contradictions give way to the perpetuation of violent policing practices, even if they coexist with the acknowledgement of human rights as morality among many soldiers.

The pacification of the favelas as a moral project crystalizes the clash between the discourse of human rights and their implementation. Ultimately, human rights becomes a polarized notion according to which those rights are conceived as an exclusive terrain of some, naturally excluding others. For one, it leads to the most evident problem, which is the violation of rights attached to the division of certain populations into social categories such as "resident" (morador) and "trafficker" (bandido). Secondly, the police themselves resent the inability to do their job properly. Indeed, the tensions between the "rise" of human rights as threat to police work and the construction of ethical soldiers reveal the deep and murky waters of the relations between the Military Police and its public in Brazil. For the soldiers, the community constantly challenges the moral, civilizing enterprise of the pacification process. For the residents, the police act with disregard of their rights. This polarization is most recently highlighted by the Military and Civil Police movements for "humanizing" the soldiers themselves, in a quest to defend "their own rights" and present themselves as having their own entitlements. In clear opposition to the "residents" and "criminals," the police are now reclaiming their own set of rights.

In Brazil, human rights are not conceived as a pre-requisite of social order and dignity, but as "something earned" that citizens must pay for. It becomes then clear how human rights are paradoxical: at the same time, their assumed goal is the protection of human dignity, yet they become so easily borrowed "to the enhancement of domination" (Perugini and Gordon 2015: 13).

Paradoxically, Amarildo's death was the beginning of the end of a program that was celebrated for reducing lethality in the favelas. Three years after Amarildo's disappearance - and pressured by social outcry -, 12 of the 25 policemen involved were condemned. ${ }^{11}$ This precedent is far from ensuring a shift towards the integration of human rights discourse within police practice. But what the pacification program and its controversies ultimately have revealed is how ongoing tensions and possibilities fragment the enterprise of integrating human rights as a moral practice among police soldiers.

11 See "Caso Amarildo: juíza condena 12 dos 25 policiais militares acusados," Globo.com, January 2, 2016, available at <http://gl.globo.com/rio-de-janeiro/noticia/2016/02/caso-amarildo-juiza-condena-l 3-dos-25-policiais-militares-acusados.html > (last access in February 2020). 


\section{REFERENCES}

ALVES, Jaime Amparo, 2014, "Neither humans nor rights: some notes on the double negation of black life in Brazil", Journal of Black Studies, 45 (2): 143-162, DOI: 10.1177/0021934714524777.

ANDRADE, Carla Lourenço Tavares de, and Célia Landmann SZWARCWALD, 2007, "Desigualdades sócio-espaciais da adequação das informações de nascimentos e óbitos do Ministério da Saúde, Brasil, 2000-2002”, Cadernos de Saúde Pública, 23 (5): 1207-1216.

AMNESTY INTERNATIONAL, 2015, You Killed My Son: Homicides by Military Police in the City of Rio de Janeiro. London, Amnesty International, available at < https://www.amnesty.o rg/download/Documents/AMR1920682015ENGLISH.PDF > (last access in February 2020).

ARIAS, Enrique Desmond, 2006, Drugs and Democracy in Rio de Janeiro: Trafficking, Social Networks, and Public Security. Chapel Hill, NC, The University of North Carolina Press.

BUENO, Samira, and Renato Sérgio de LIMA (eds.), 2019, Anuário Brasileiro de Segurança Pública 2019. São Paulo, Fórum Brasileiro de Segurança Pública.

CALDEIRA, Teresa P. R, 2006, “'I came to sabotage your reasoning!': violence and resignifications of justice in Brazil", in J. Comaroff and J. Comaroff (eds.), Law and Disorder in the Postcolony. Chicago, The University of Chicago Press, 102-149.

CANO, Ignacio, 2006, "Public security policies in Brazil: attempts to modernize and democratize versus the war on crime", Sur: Revista Internacional de Direitos Humanos, 3 (5): 136-155, DOI: 10.1590/S1806-64452006000200007.

CARDOSO, Marcus, 2012, "Polícia e direitos na visão dos moradores de duas favelas do Rio de Janeiro", Estudos de Sociologia, 17 (33): 491-507.

FASSIN, Didier, 2011 1, La force de l'ordre: une anthropologie de la police des quartiers. Paris, Seuil.

FASSIN, Didier, 2013, "On resentment and ressentiment: the politics and ethics of moral emotions”, Current Anthropology, 54 (3): 249-267, DOI: 10.1086/670390.

GOldstein, Daniel M., 2012, Outlawed: Between Security and Rights in a Bolivian City. Durham, Duke University Press Books.

GOODALE, Mark, 2012, "Human rights", in D. Fassin (ed.), A Companion to Moral Anthropology, Chichester, Wiley-Blackwell, 468-481.

HORNBERGER, Julia, 2010, "Human rights and policing: exigency or incongruence?", Annual Review of Law and Social Science, 6 (1): 259-283, DOI: 10.1 146/annurev-lawsocs ci-102209-152830.

HUMAN RIGHTS WATCH, 2009, Lethal Force: Police Violence and Public Security in Rio de Janeiro and São Paulo. New York, Human Rights Watch, available at < https://www.hrw.or g/report/2009/12/08/lethal-force/police-violence-and-public-security-rio-de-janeiro-andsao-paulo $>$ (last access in February 2020).

Jauregui, Beatrice, 2016, Provisional Authority: Police, Order, and Security in India. Chicago, The University of Chicago Press.

LARKINS, Erika Robb, 2011 , The Spectacular Favela: Narcotrafficking, Policing, and the Commodification of Violence in Rio de Janeiro. Madison, University of Wisconsin, doctoral dissertation.

LEANDRO, Sylvia Amanda da Silva, and Luiz Eduardo FIGUEIRA, 2014, “Não me venha com direitos humanos': por uma compreensão do sujeito no 'homicídio por auto de resistência'”, Dilemas, 7 (2): 261-291. 
LEITE, Márcia Pereira, 2012, “Da 'metáfora da guerra' ao projeto de 'pacificação': favelas e políticas de segurança pública no Rio de Janeiro”, Revista Brasileira de Segurança Pública, $6(2): 374-389$.

LEITE, Márcia Pereira, 2014, “Entre a 'guerra' e a 'paz': Unidades de Polícia Pacificadora e gestão dos territórios de favela no Rio de Janeiro”, Dilemas, 7 (4): 625-642.

MENEZES, Palloma Valle, 2014, “Os rumores da 'pacificação': a chegada da UPP e as mudanças nos problemas públicos no Santa Marta e na Cidade de Deus”, Dilemas, 7 (4): 665 -684 .

MENEZES, Palloma, 2018, “O problema da aproximação no 'policiamento de proximidade': reflexões sobre a experiência das Unidades de Polícia Pacificadora em favelas do Rio de Janeiro", Trabajo y Sociedad, 31: 51-73.

MERRY, S. E., 2006, "Transnational human rights and local activism: mapping the middle", American Anthropologist, 108: 38-51.

MIRANDA, Ana Paula Mendes de, 2014, "Militarização e direitos humanos: gramáticas em disputa nas políticas de segurança pública no Rio de Janeiro/Brasil”, Forum Sociológico, s. II, 25: 1 1-22, DOI: 10.4000/sociologico.886.

PERlMAN, Janice, 2010, Favela: Four Decades of Living on the Edge in Rio de Janeiro. Oxford, Oxford University Press.

PERUGINI, Nicola, and Neve GORDON, 2015, The Human Right to Dominate. Oxford, Oxford University Press.

SCHEPER-HUGHES, Nancy, 2006, "Death squads and democracy in Northeast Brazil", in J. Comaroff and J. Comaroff (eds.), Law and Disorder in the Postcolony. Chicago, The University of Chicago Press, 150-187.

SILVA, Kelly, 2014, "Da resistência à violência de Estado a um novo projeto de formação nacional: genealogias das políticas de direitos humanos no Brasil”, Anuário Antropológico, 2014 (1): 39-71.

SILVA, Luiz Antonio Machado da, 2011 , "Polícia e violência urbana em uma cidade brasileira”, Etnográfica, 15 (1): 67-82, DOI: 10.4000/etnografica.828.

SILVA, Luiz Antonio Machado da, and Márcia Pereira LEITE, 2014, "Continuidades e mudanças em favelas 'pacificadas': apresentação ao dossiê Unidades de Polícia Pacificadora - Cevis”, Dilemas, 7 (4): 607-610.

WACQUANT, Loïc, 2008, “The militarization of urban marginality: lessons from the Brazilian metropolis", International Political Sociology, 2 (1): 56-74, DOI: 10.1111/j.1749-568 7.2008.00037.x.

WEBER, Max, 2004, The Vocation Lectures. Indianapolis, IN, Hackett Publishing Company.

WILlIS, Graham Denyer, 2015, The Killing Consensus: Police, Organized Crime, and the Regulation of Life and Death in Urban Brazil. Oakland, CA, University of California Press.

ZALUAR, Alba, and Marcos AlviTO, 1998, Um Século de Favela. Rio de Janeiro, FGV Editora. 